MATEC Web of Conferences 5, 04045 (2013)

DOI: $10.1051 /$ matecconf $/ 20130504045$

(c) Owned by the authors, published by EDP Sciences, 2013

\title{
ERRATUM
}

\section{Study of the surface size defects in the case of a soda lime glass eroded by sandblasting}

\author{
A. Faci, M. Kolli, N. Bouaouadja and C. Bousbaa \\ Laboratory of Non-Metallic Materials, I.O.P.M., F. Abbas University, Sétif 19000, Algeria
}

MATEC Web of Conferences 5, 04038 (2013)

DOI: $10.1051 /$ matecconf/20130504038

The name of the last author should be C. Bousbaa instead of B. Chabane.

This is an Open Access article distributed under the terms of the Creative Commons Attribution License 2.0, which permits unrestricted use, distribution, and reproduction in any medium, provided the original work is properly cited. 